\title{
Landsat Images and Artificial Intelligences Techniques used to Map Pyroclastic Material Following the Eruption of Mount Agung Indonesia
}

\author{
Mutiara Syifa ${ }^{1}$, Prima Riza Kadavi ${ }^{1}$, Chang-Wook Lee ${ }^{1 *}$, and Biswajeet \\ Pradhan $^{2}$ \\ ${ }^{1}$ Division of Science Education, Kangwon National University, 1 \\ Kangwondaehak-gil, Chuncheon-si, Gangwon-do, 24341, South Korea. \\ ${ }^{2}$ School of Systems, Management and Leadership, Faculty of Engineering \\ and IT, University of Technology Sydney, Sydney, Australia \\ Mutiara Syifa: mutiarsyifa@gmail.com \\ Prima Riza Kadavi: rizakadavi@gmail.com \\ Biswajeet Pradhan: Biswajeet.Pradhan@uts.edu.au \\ Chang-Wook Lee*: cwlee@kangwon.ac.kr

\section{* Corresponding author \\ Chang-Wook Lee}

Division of Science Education, Kangwon National University, 1 Kangwondaehak-gil, Chuncheon-si, Gangwon-do, 24341, South Korea. Tel.:+82-33-250-6731, cwlee@kangwon.ac.kr

\begin{abstract}
Of the 829 active volcanoes distributed worldwide, 129 are located in Indonesia. Two recent eruptions of Mount Agung on Bali Island, Indonesia, on November 21, 2017 and January 11, 2018, produced massive ash, steam, and gas emissions. Rainwater carried these pyroclastic materials in cold lahars to southwestern parts of the island. Because explosive eruptions of Mount Agung during 1963-1964 produced voluminous ashfall and catastrophic pyroclastic flows, the monitoring of this volcano has been considered essential. Land cover (LC) mapping is one method commonly used to monitor the spread of materials in volcanic areas due to the inaccessibility of field data during ongoing eruptions. In this paper, we analyzed multispectral data using two different classifiers: an artificial neural network (ANN) and a support vector machine (SVM). Landsat imagery was used to generate a LC map with four feature classes: rock and sand, vegetation, cloud, and shadow. The ANN method was more accurate than the SVM method, with classification accuracies of $94.67 \%$
\end{abstract}


and $97 \%$ for the first and second Mount Agung eruptions, respectively. The SVM classifier was better than ANN at classifying images taken prior to eruption, with an overall accuracy of $91.60 \%$. Thus, both classifiers accurately distinguished eruption products and environmental features, and are suitable for LC classification in volcanic regions.

Keywords: Artificial neural network, geographic information system, remote sensing, Mount Agung, support vector machine, volcanic eruption.

\section{Introduction}

Of the 829 active volcanoes distributed worldwide, 129 are located in Indonesia. In 1963-1964, the most massive explosive eruption to occur in Indonesia in the $20^{\text {th }}$ century took place on Mount Agung, producing voluminous ashfall and catastrophic pyroclastic flows. Since that time, almost no activity was reported from Agung, until mid-August 2017, when seismic activity was recorded (Global Volcanism Program, 2018). The Center for Volcanology and Geological Hazard Mitigation in Indonesia incrementally raised the alert level from I to IV (lowest to highest) between September 14 and 22, 2017 as the rate of seismic events increased (Global Volcanism Program, 2018). The first ash emission appeared on November 21, 2017, increasing 700 $\mathrm{m}$ above the summit and causing environmental damage, air travel disruption, and the evacuation of thousands of people. During the following week, ash plume heights increased to approximately $3,000 \mathrm{~m}$; ash and steam emission continued until the second eruption on January 11, 2018. Because the eruption occurred during the rainy season, materials emitted from Mount Agung were carried by rainwater as cold lahar floods into the Sabuh River and Yeh Asa River to the south and southwest of Mount Agung, respectively.

Because lava flows, ash falls, and lahars can cause losses such as human casualties, property damage, and environmental degradation (Blong, 1984), damage assessments from remote sensing images are needed. Land cover (LC) mapping is a commonly used monitoring strategy that can incorporate predictive flow models or risk zonation, which can be particularly useful for developing countries, where the damage caused by volcano eruptions to growing populations is continually increasing. Kadavi (2017) reported that remote sensing imagery could help to monitor the spread of atmospheric eruptive fumes, pyroclastic deposits, incandescent lava, lahar distribution, and dome deformation. Thus, the use of remote sensing technologies can define a new paradigm for volcanology activity observations (Pieri and Abrams, 2004) that is advantageous in all phases of volcanic eruptions disaster management (Van Westen, 2000). 
Remote sensing provides a systematic, concise framework for advancing scientific knowledge of the Earth through interacting processes that can include natural disasters and their effects (Tralli, 2005). Remote sensing provides geospatial information products that address the operational requirements of multi-hazard decision support tools and systems. For example, policymakers, responders, and emergency managers from local to global scales can generate scenarios, map out mitigation plans, and design the most effective response measures using remote sensing imagery.

Multiple types of satellite-borne sensors such as the Satellite Pour l'Observation de la Terre, Landsat, and the Advanced Spaceborne Thermal Emission and Reflection Radiometer (ASTER) can provide data suitable for debris mapping, and allow researchers to obtain high-spatial-resolution satellite images (Kerle et al., 2003; Joyce et al., 2008). Techniques for the visual interpretation of changes in images due to volcanic activity include multiband displays, which incorporate images from different input dates (Calomarde, 1998; Castro and Carranza, 2005), principal components analyses, and image subtraction (Torres et al., 2004). Image classification can involve artificial neural networks (ANNs, Foody, 2000), support vector machines (SVMs, Watanachaturaporn \& Arora, 2004), and decision tree methods (Hansen et al., 1996; Pal, 2003); classified images are integrated by remote sensing image processing software such as PCI Geomatica, Earth Resource Development Assessment System (ERDAS), and Environment for Visualizing Images (ENVI) (Liu, 2014). Recently, numerous studies have demonstrated that ANNs and SVMs can provide alternative methodologies for classification problems to which traditional statistical approaches have long been applied (Tseng, 2008).

Although the use of satellite imagery in natural hazard damage or disaster assessment and prediction can be very cost effective and time effective, this approach has some drawbacks. A lack of spatial resolution and radiometric sensitivity are often caused by small-scale monitoring of volcanic activity is required. For example, plumes are better monitored with higher-resolution sensors such as ASTER (Realmuto et al., 1997; Pugnaghi et al., 2006), although its less frequent overpasses compromise temporal variability monitoring.

Atmospheric disturbances such as clouds, haze, and smoke create significant problems in passive optical imagery analyses because they block parts of the image and can cause distortion (Zhan et al., 2005). Often, these clouded and shadowed areas must be excluded from damage assessment analyses, resulting in gaps in the data. Active sensors such as radar, Global Positioning System, or Light Detection and Ranging can avoid this problem; however significant limitations remain due to large pixel sizes, classification accuracy, and revisit times (Sanyal and Lu, 2004). The temporal resolutions of active and passive sensors can also pose a problem in real-time damage assessments of natural hazards. Sensors such as the Moderate Resolution Imaging Spectroradiometer have a daily revisit time, whereas sensors on satellites such as Landsat and 
IKONOS have longer revisit times. Earthquakes, volcanic eruptions, landslides, and floods can occur very quickly; the peak of the disaster may only persist for a few hours, such that it may not be captured by sensors (Sanyal and $\mathrm{Lu}, 2004)$.

In this study, we acquired Landsat images of the Mount Agung eruptions in 2017 and 2018, and employed ANN and SVM classification methodologies. We compared the accuracies of the SVM and ANN classification methods for processed data collected around the Mount Agung volcanic eruptions, and examined the resulting LC data to predict disaster-prone areas around Mount Agung.

\section{Study Area}

Mount Agung is an active stratovolcano with a broad, deep crater 3,142 m above sea level; it is the highest peak in Bali, Indonesia (Fig. 1a). The volcano is located at latitude $8^{\circ} 25^{\prime} \mathrm{S}$ and longitude $115^{\circ} 30^{\prime} \mathrm{E}$ in eastern Bali Island and is part of the Sunda volcanic arc, which overlies northward-dipping oceanic crust subducted at the Java trench, in the Indian Ocean south of Bali (Whitford, 1975). The volcanic cone is steep and almost barren at the top, with an open, funnel-shaped crater $520 \mathrm{~m} \times 375 \mathrm{~m}$ in area (Dilmy, 1965). Mount Agung lies just outside and southeast of Mount Batur (Fig. 1b) (Wheller and Varne, 1986). Nearly one million people live within a $30 \mathrm{~km}$ radius of Mount Agung, which has great religious significance for the Balinese people (Gertisser, 2018).

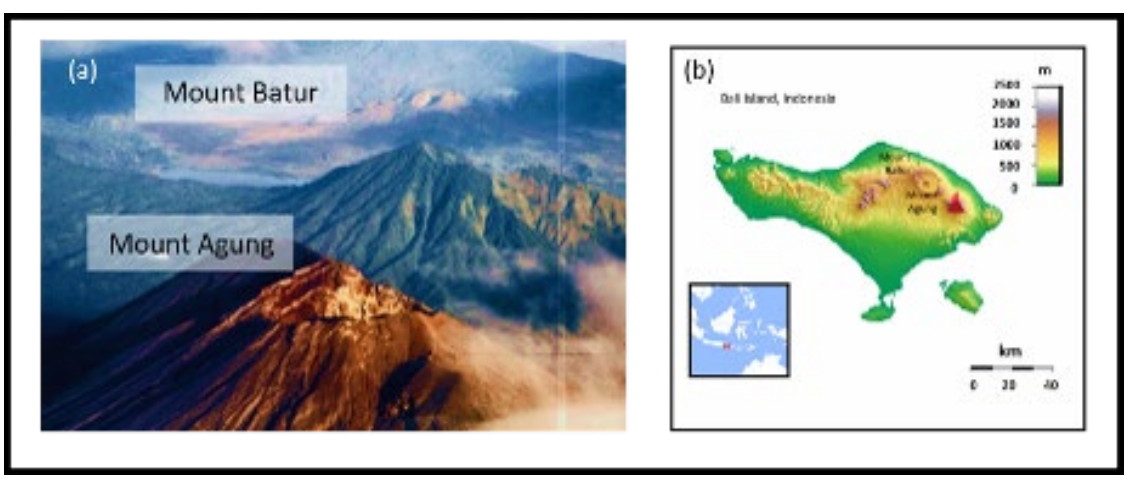

Figure 1. (a) The Mount Agung crater; Mount Batur is shown in the background. (b) The location of Mount Agung within Bali Island.

Mount Agung is one of many volcanoes in Indonesia that have a minimal written record, probably due to their long dormancy. The earliest recorded eruption of Mount Agung occurred in 1843; there exists no systematic written 
record of volcanic eruptions in Indonesia during this period. After 1843, increased solfataric activities were recorded until 1963, when catastrophic eruptions occurred, culminating in two massive explosions on March 17 and May 16, 1963. Previous Mount Agung eruptions in 1808, 1821, 1843, and 1963 exhibited similar types of eruptions, both explosive (emitting sparks, lava fragments, pyroclastic rain, and ash), and effusive (hot cloud flow and lava flow) (Kusumadinata, 1979). On November 21, 2017, Mount Agung erupted again, beginning with a phreatic (steam) explosion that emitted pulverized volcanic rock and generated a $700 \mathrm{~m}$ eruption column above the volcano (Fig. 2a). Further explosions within the following few days caused ashfall and cold lahars to the southwest of the volcano (Fig. 2c). Explosive events on January 11 (Fig. $2 \mathrm{~b}$ ) and 15,2018 produced $2.5 \mathrm{~km}$ ash plumes above the volcano, causing thin ashfall in downwind areas. As of 20 January 2018, ash and steam plumes persisted above the Mount Agung crater rim, high-frequency volcanic earthquakes dominated the seismic activity, and the region remained at the highest alert level (Gertisser, 2018). A map of disaster-prone areas and the dominant ejected materials is shown in Figure 3. In this study, we used Landsat7 images to capture the conditions following the first eruption, and Landsat-8 images to capture pre-eruption conditions and current conditions, due to cloud cover.

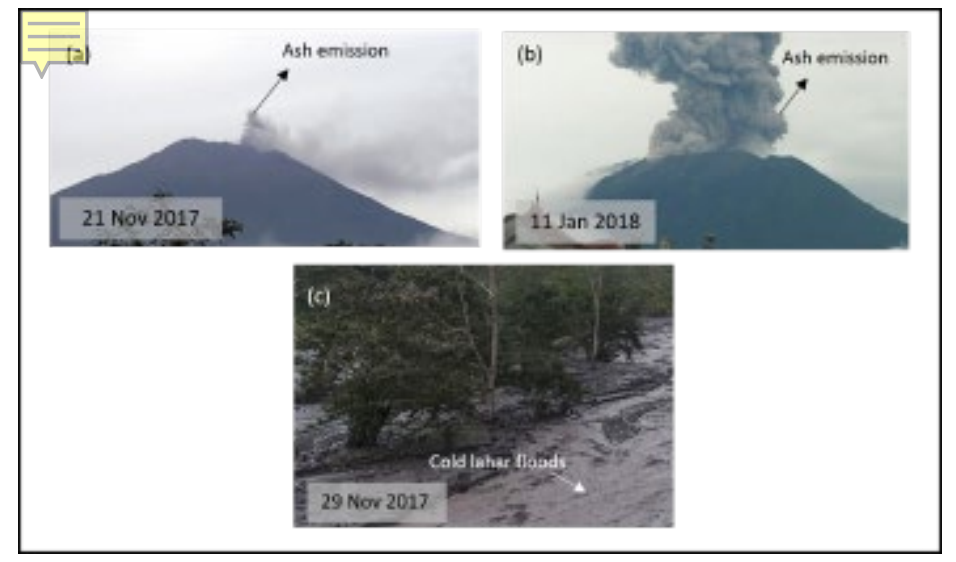

Figure 2. (a) The first reported ash emission from Mount Agung drifted southwestward on November 21, 2017. (b) Mount Agung emitted a 2,500 $\mathrm{m}$ ash plume above its crater on January 11, 2018; tremors were also observed. (c) Continued ashfall on the slopes of Mount Agung carried by rainwater caused cold lahar flows in Muncan Village, Karangasem, Bali, November 29, 2017. 


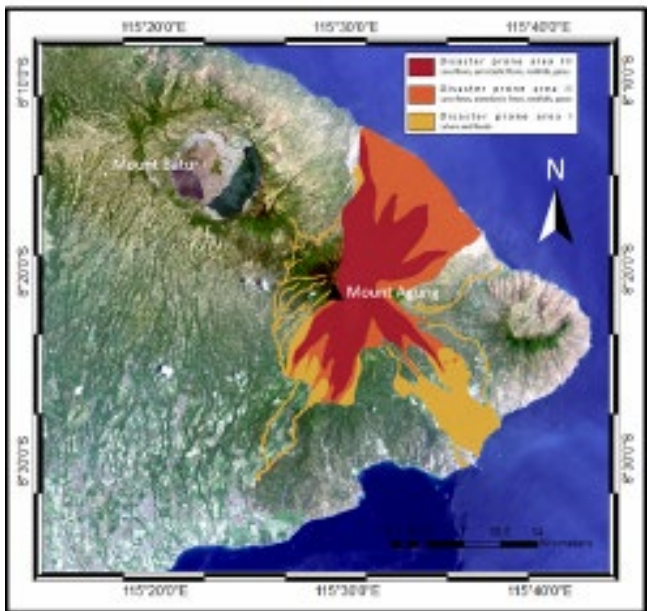

Figure 3. Map of disaster-prone areas around Mount Agung (Center for Volcanology and Geological Hazard Mitigation [29 Spetember 2017]).

\section{Landsat Imagery Data}

Landsat-7 (Fig. 4b) RGB bands 7, 4, and 2 were used for Mount Agung LC classification of post-eruption images taken on December 8, 2017. Landsat-8 RGB (Fig. 4a, c) bands 7, 5, and 3 were used for LC classification of preeruption images acquired on September 13, 2017 and of images acquired April 23, 2018, showing the current conditions on Mount Agung. Satellite images were selected based on the apparent LC (vegetation, rock, and soil). The distribution of volcanic material ejected from Mount Agung including cold lahar, rock, and sand was classified to distinguish it from other objects such as vegetation and cloud. However, many of the Landsat images were inevitably covered by cloud, particularly in the tropics (Asner, 2001). Because Indonesia is a tropical country, obtaining clear Landsat images for use in the current study was a challenge. The Landsat images are classified into four classes; the classification scheme and category definitions are listed in Table 1. 


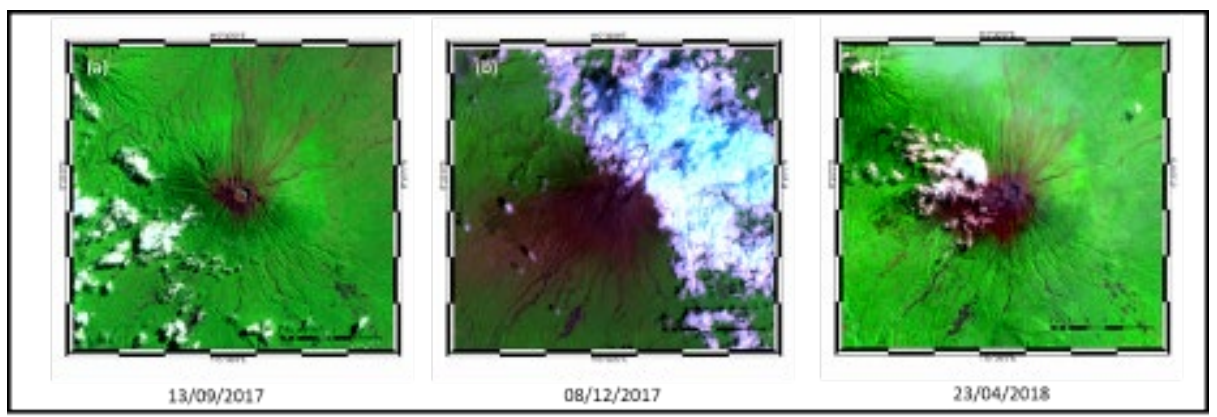

Figure 4. Landsat imagery data for Mount Agung (a) acquired on September 13, 2017 (Landsat-8), before the first eruption; (b) acquired on December 8, 2017 (Landsat-7), before the first eruption; and (c) acquired on April 23, 2018 (Landsat-8), after the second eruption. Landsat- 8 RGB bands 7, 5, and 3 and Landsat-7 RGB bands 7, 4, and 2 were used.

Table 1. Land cover (LC) classification scheme and class definitions for the study area on Mount Agung in Bali, Indonesia.

\begin{tabular}{lll}
\hline $\begin{array}{c}\text { Class } \\
\text { number }\end{array}$ & Class name & Class definition \\
\hline 1 & $\begin{array}{l}\text { Rock and } \\
\text { sand }\end{array}$ & $\begin{array}{l}\text { Volcanic eruption products such as rock, } \\
\text { sand, and pyroclastic materials. }\end{array}$ \\
2 & Vegetation & $\begin{array}{l}\text { Natural upland forest including grass and } \\
\text { trees }\end{array}$ \\
3 & Cloud & $\begin{array}{l}\text { All areas covered by cloud } \\
\text { Shadowed areas }\end{array}$ \\
\hline
\end{tabular}

\section{Methodology}

Erupted ash and pyroclastic material do not form specific spatial patterns (Smith, 2002) and must therefore be mapped based on spectral or temporal contrasts (Mazher, 2012). In the current study, we first examined different classification approaches to determine which was more accurate. Our approach consisted of three phases: extracting the most appropriate features, comparing classification methods, and assessing the accuracy of these methods (Fig. 5). 


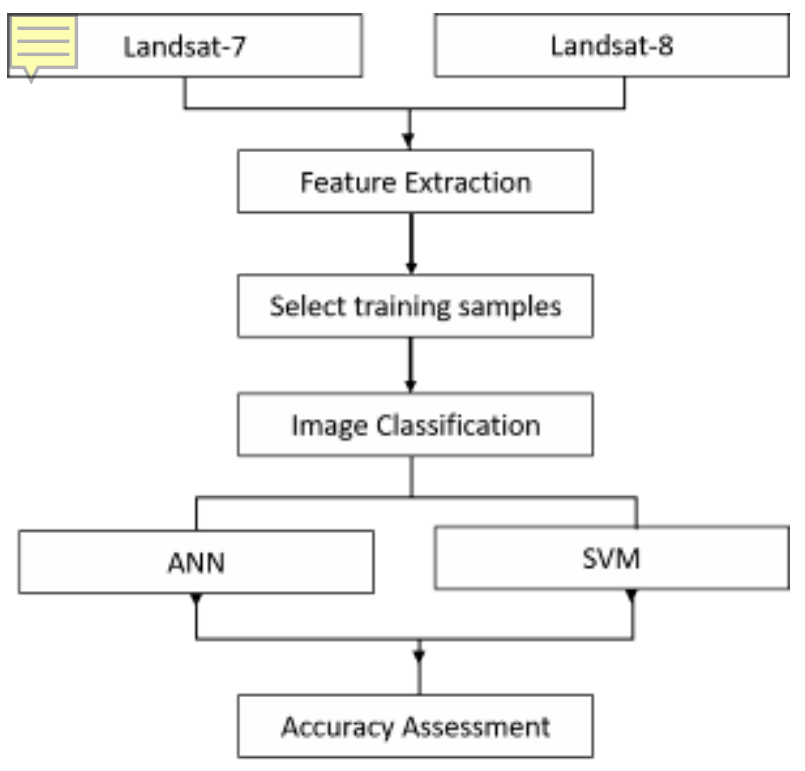

Figure 5. A flowchart of the methodology used in this study to determine the effectiveness of the artificial neural network (ANN) and support vector machine (SVM) classification approaches for selected images.

\subsection{ANN Classification}

ANNs are used in LC mapping for pattern recognition and the classification of image data (Hepner, 1990) from remotely sensed satellite data (Foody, 1996), which consist of one input layer, at least one hidden layer, and one output layer. Each layer in an ANN is formed by nonlinear processing units (i.e., neurons); the connections between neurons in successive layers are weighted (Xiu, 2013). In the current study, we employed the architecture of network and training patterns suggested by Kavzoglu (2009) and a logistic activation model. The Mount Agung area was classified into four groups, with five training samples per group. These groups consisted of rock and sand, vegetation, cloud, and shadow; each was differentiated by color using RGB Landsat images. The training threshold contribution and training momentum field were set to 0.9; the training rate field, number of training iterations, and training RMS exit criteria field were set to $0.2,1000$, and 0.1 , respectively.

\subsection{SVM Classification}


SVM is another machine learning technique that has been applied in the classification of remote sensing data (Dixon and Candade, 2008; Yao et al., 2008). Like ANN and other nonparametric classifiers, it is a robust classification approach (Foody and Mathur, 2004a; Foody and Mathur, 2004b). SVM separates image data into classes using a decision surface that maximizes the differences among the classes ( $\mathrm{Lu}, 2012)$. In this study, we applied the ANN and SVM approaches to the same images, using the same training samples. The SVM classifier features four types of common kernels: polynomial, linear, radial basis function (RBF), and sigmoid (Liu, 2013). Of these, we selected the RBF kernel due to its wide applicability and capacity to facilitate excellent nonlinear classification (Mountrakis, 2011; Zhai, 2014). The gamma value was set to 0.33 , the penalty parameter was set to 100 , and the pyramid parameter was set to 0 to process each image in full resolution. A classification probability threshold of zero was selected to force the assignment of a class label to all image pixels..

\section{Results and Discussion}

Landsat-7 and Landsat-8 images of Mount Agung were classified using the ANN and SVM methods. Each classified the image data into four groups: rock and sand, vegetation (trees and grass), cloud, and shadow. A stratified sampling method was applied on a pixel-by-pixel basis to assess classification accuracy. Pixels representing each class were randomly selected from the Landsat maps to assess the accuracy of the classification method. Error matrices were generated by visually interpreting the $30 \mathrm{~m}$ resolution images and the corresponding Landsat 7 images. The kappa coefficient was used to assess accuracy by dividing the amount of agreement between results by the amount that would be expected by chance (Cohen, 1960); thus, it is a measure of the proportionate reduction in error (i.e., the extent to which the results indicate statistical non-independence). The kappa coefficient adjusts for some of the differences between matrices, and thus can be used to compare results for different regions or different classifications (Khorram et al., 1999). Therefore, we calculated the kappa coefficient of each error matrix to determine whether one classifier was significantly better than the other.

\subsection{Images Acquired Prior to the First Eruption}

\subsubsection{Land Classification Map}

Mount Agung was classified into four groups based on the colors in the Landsat-8 images. These groups included rock and sand, vegetation (including houses), cloud, and shadow (Fig. 6). The images were trained into five random 
polygon samples for each class (20 samples in total) to obtain the LC result. For images acquired on September 13, 2017, prior to the first eruption, SVM generated better recognition than ANN. SVM was computationally more efficient and better able to distinguish cloud from rock and sand. Images of the northern part of Mount Agung were free of cloud; however, the ANN classified darker vegetation cover as cloud, which are visually distinct (Fig. 4). Prior to the eruption on November 2017, the top of Mount Agung was covered only by volcanic rock and sand.

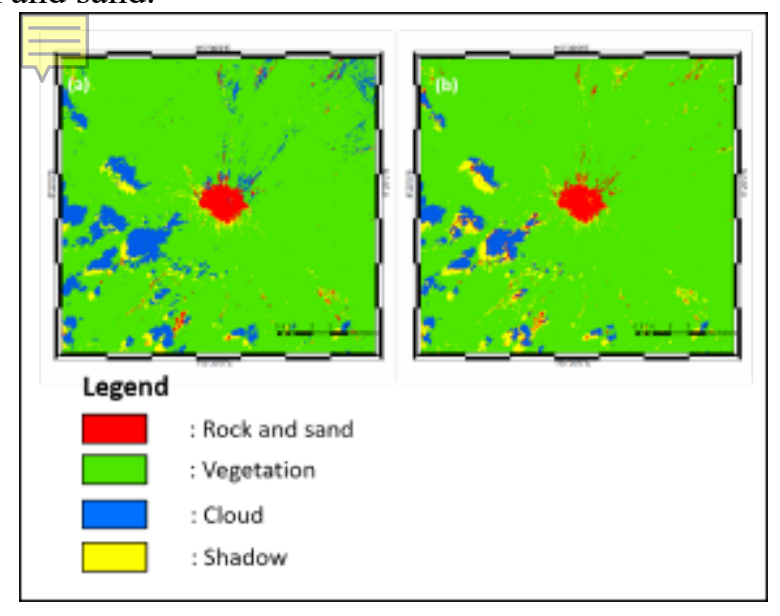

Figure 6. Land classification maps of Mount Agung before the November 2017 eruption created using Landsat-8 images with (a) ANN and (b) SVM classification. The images were classified into four land cover (LC) classes: rock and sand (red), vegetation (green), cloud (blue), and shadow (yellow).

\subsubsection{Accuracy Assessment}

Tables 2 and 3 show the error matrix for the LC classification map of Mount Agung prior to the first eruption using the ANN and SVM methods, respectively. Both methods used 405 pixels: 89 for rock and sand, 118 for vegetation, 108 for cloud, and 90 for shadow. All sample data were based on the LC area and its spread. For example, the rock and sand class contained the lowest number because its LC was lowest among the groups. The accuracy of the SVM method $(91.60 \%)$ was much higher than that of the ANN method $(91.36 \%)$. The accuracies of the user and producer results were high in most classes; however, producer accuracy was lower for the rock and sand class than for all other classes under both ANN (74.16\%) and SVM (78.65\%), due to the identification of darker vegetation as rock and sand. The Kappa coefficient for the ANN method was $90.54 \%$ and that of SVM was $90.78 \%$. 
Table 2. Error matrix for LC map of Mount Agung before the first eruption classified using the artificial neural network (ANN) method.

\begin{tabular}{|c|c|c|c|c|c|c|}
\hline & $\begin{array}{l}\text { Rock } \\
\text { and sand }\end{array}$ & $\begin{array}{l}\text { Veget } \\
\text { ation }\end{array}$ & $\begin{array}{l}\text { Clo } \\
\text { ud }\end{array}$ & $\begin{array}{l}\text { Sha } \\
\text { dow }\end{array}$ & $\begin{array}{l}\text { Class } \\
\text { totals }\end{array}$ & $\begin{array}{l}\text { User } \\
\text { accuracy } \\
(\%) \\
\end{array}$ \\
\hline Rock and sand & 66 & 0 & 0 & 3 & 69 & 96 \\
\hline Vegetation & 10 & 115 & 0 & 6 & 131 & 87.79 \\
\hline Cloud & 11 & 2 & 108 & 0 & 121 & 89.26 \\
\hline Shadow & 2 & 1 & 0 & 81 & 84 & 96.43 \\
\hline $\begin{array}{l}\text { Reference } \\
\text { totals }\end{array}$ & 89 & 118 & 108 & 90 & 405 & \\
\hline $\begin{array}{l}\text { Producer } \\
\text { accuracy }(\%)\end{array}$ & 74.1 & 97 & 100 & 90 & & \\
\hline $\begin{array}{l}\text { Overall } \\
\text { accuracy (\%) }\end{array}$ & 91.36 & 91.36 & & & & \\
\hline $\begin{array}{l}\text { Kappa } \\
\text { coefficient } \\
(\%)\end{array}$ & 90.54 & 90.54 & & & & \\
\hline
\end{tabular}

Table 3. Error matrix for LC map of Mount Agung before the first eruption classified using the support vector machine (SVM) method.

\begin{tabular}{lllllll}
\hline & $\begin{array}{l}\text { Rock } \\
\text { and sand }\end{array}$ & $\begin{array}{l}\text { Veget } \\
\text { ation }\end{array}$ & $\begin{array}{l}\text { Clo } \\
\text { ud }\end{array}$ & $\begin{array}{l}\text { Sha } \\
\text { dow }\end{array}$ & $\begin{array}{l}\text { Class } \\
\text { totals }\end{array}$ & $\begin{array}{c}\text { User } \\
\text { accuracy } \\
\text { (\%) }\end{array}$ \\
\hline $\begin{array}{l}\text { Rock and } \\
\text { sand }\end{array}$ & 70 & 0 & 0 & 2 & 72 & 97 \\
$\begin{array}{l}\text { Vegetation } \\
\text { Cloud }\end{array}$ & 15 & 117 & 2 & 8 & 142 & 82.39 \\
Shadow & 4 & 0 & 104 & 0 & 104 & 100.00 \\
$\begin{array}{l}\text { Reference } \\
\text { totals }\end{array}$ & 89 & 1 & 2 & 80 & 87 & 91.95 \\
$\begin{array}{l}\text { Producer } \\
\text { accuracy (\%) }\end{array}$ & 78.65 & 99 & 96 & 89 & & \\
$\begin{array}{l}\text { Overall } \\
\text { accuracy (\%) }\end{array}$ & 91.60 & 91.60 & & & & \\
\hline
\end{tabular}




\begin{tabular}{lll}
\hline $\begin{array}{l}\text { Kappa } \\
\text { coefficient } \\
(\%)\end{array}$ & 90.78 & 90.78 \\
\hline
\end{tabular}

\subsection{Images Acquired After the First Eruption}

\subsubsection{LC Maps}

The image of Mount Agung acquired after the first eruption was also divided into four classes: volcanic rock and sand, vegetation, cloud, and shadow. We used 20 random training samples in total (five samples per class). The results of ANN classification are shown in Figure 7a and those of SVM classification are shown in Figure 7b. Both methods produced similar results; however, there were some differences. Because the acquired image was extremely cloudy, the classification results obtained by both methods were dominated by blue color. The ANN method identified some of the darker vegetation areas as rock and sand, particularly in the northern part of Mount Agung. SVM classified some darker vegetation as shadow, as shown in the southern and northern parts of the images (Fig. 7b).

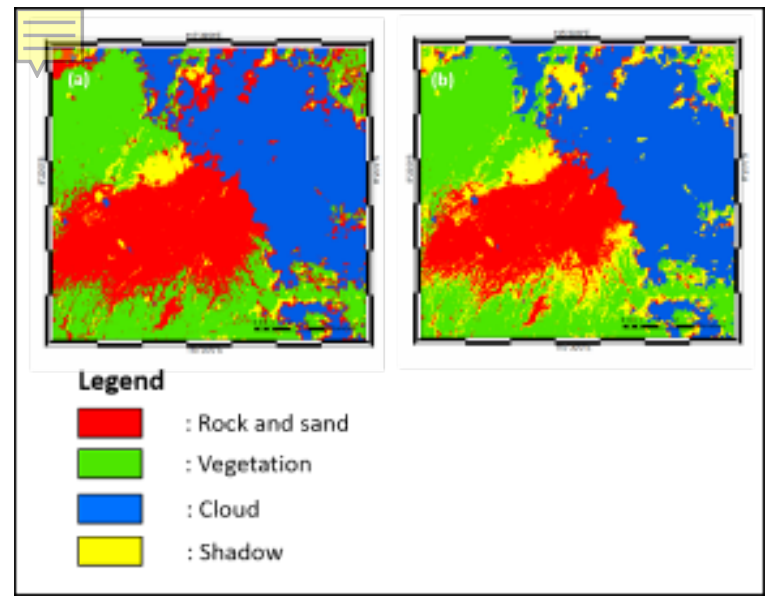

Figure 7. LC maps of Mount Agung after the first eruption created from Landsat-7 images classified using (a) ANN and (b) SVM. LC was classified into four classes: rock and sand (red), vegetation (green), cloud (blue), and shadow (yellow).

\subsubsection{Accuracy Assessment}


The ANN and SVM error matrices were generated using 507 test pixels: 119 for rock and sand, 110 for vegetation, 137 for cloud, and 141 for shadow. Accuracy assessment results for the ANN and SVM classification of the image acquired after the first eruption image are shown in Tables 4 and 5. ANN and SVM provided very similar overall accuracies, at $94.67 \%$ and $94.28 \%$, respectively. The results were very similar between methods; however, the user accuracy results for the rock and sand class were significantly different, with $92 \%$ for ANN and $82 \%$ for SVM. The kappa coefficients for ANN and SVM were 93.96 and $93.46 \%$, respectively.

Table 4. Error matrix for LC map of Mount Agung after the first eruption classified using the ANN method.

\begin{tabular}{|c|c|c|c|c|c|c|}
\hline & $\begin{array}{l}\text { Rock } \\
\text { and sand }\end{array}$ & $\begin{array}{l}\text { Veget } \\
\text { ation }\end{array}$ & $\begin{array}{l}\text { Clo } \\
\text { ud }\end{array}$ & $\begin{array}{l}\text { Sha } \\
\text { dow }\end{array}$ & $\begin{array}{l}\text { Class } \\
\text { totals }\end{array}$ & $\begin{array}{l}\text { User } \\
\text { accuracy } \\
(\%)\end{array}$ \\
\hline Rock and sand & 92 & 5 & 3 & 0 & 100 & 92 \\
\hline Vegetation & 0 & 111 & 2 & 0 & 113 & 98.23 \\
\hline Cloud & 5 & 10 & 136 & 2 & 153 & 88.89 \\
\hline Shadow & 0 & 0 & 0 & 141 & 141 & 100.00 \\
\hline $\begin{array}{l}\text { Reference } \\
\text { totals }\end{array}$ & 97 & 126 & 141 & 143 & 507 & \\
\hline $\begin{array}{l}\text { Producer } \\
\text { accuracy }(\%)\end{array}$ & 94.85 & 88 & 96 & 99 & & \\
\hline $\begin{array}{l}\text { Overall } \\
\text { accuracy }(\%)\end{array}$ & 94.67 & 94.67 & & & & \\
\hline $\begin{array}{l}\text { Kappa } \\
\text { coefficient } \\
(\%)\end{array}$ & 93.96 & 93.96 & & & & \\
\hline
\end{tabular}

Table 5. Error matrix for LC map of Mount Agung after the first eruption classified using the SVM method. 


\begin{tabular}{lllllll}
\hline & $\begin{array}{l}\text { Rock } \\
\text { and sand }\end{array}$ & $\begin{array}{l}\text { Veget } \\
\text { ation }\end{array}$ & $\begin{array}{l}\text { Clo } \\
\text { ud }\end{array}$ & $\begin{array}{l}\text { Sha } \\
\text { dow }\end{array}$ & $\begin{array}{l}\text { Class } \\
\text { totals }\end{array}$ & $\begin{array}{l}\text { User } \\
\text { accuracy } \\
(\%)\end{array}$ \\
\hline $\begin{array}{l}\text { Rock and } \\
\text { sand }\end{array}$ & 97 & 12 & 9 & 1 & 119 & 82 \\
$\begin{array}{l}\text { Vegetation } \\
\text { Cloud }\end{array}$ & 0 & 109 & 1 & 0 & 110 & 99.09 \\
$\begin{array}{l}\text { Shadow } \\
\text { Reference }\end{array}$ & 0 & 5 & 131 & 1 & 137 & 95.62 \\
totals & 97 & 0 & 0 & 141 & 141 & 100.00 \\
$\begin{array}{l}\text { Producer } \\
\text { accuracy (\%) }\end{array}$ & 100.00 & 87 & 93 & 99 & & \\
$\begin{array}{l}\text { Overall } \\
\text { accuracy }(\%)\end{array}$ & 94.28 & 94.28 & & & & \\
$\begin{array}{l}\text { Kappa } \\
\text { coefficient } \\
\text { (\%) }\end{array}$ & 93.46 & 93.46 & & & & \\
\hline
\end{tabular}

\subsection{Images Acquired After the Second Eruption}

\subsubsection{LC Maps}

LC maps of Mount Agung after the second eruption are shown in Figure 8. The image was divided into four classes based on color: red for pyroclastic material including volcanic rock and sand, green for vegetation, blue for cloud, and yellow for shadow. For this image, we selected 20 random polygon samples in total for training (five samples per class). The ANN method yielded a better result than SVM, which misclassified some light vegetation as cloud. Some darker vegetation was also classified as shadow, particularly in the northwestern parts of Mount Agung. Similar results for the other classes were obtained by both methods; notably, pyroclastic material was shown to have the same flow direction as the first eruption (i.e., to the southwest). These images were acquired on April 23, 2018; therefore, little pyroclastic material remained. 


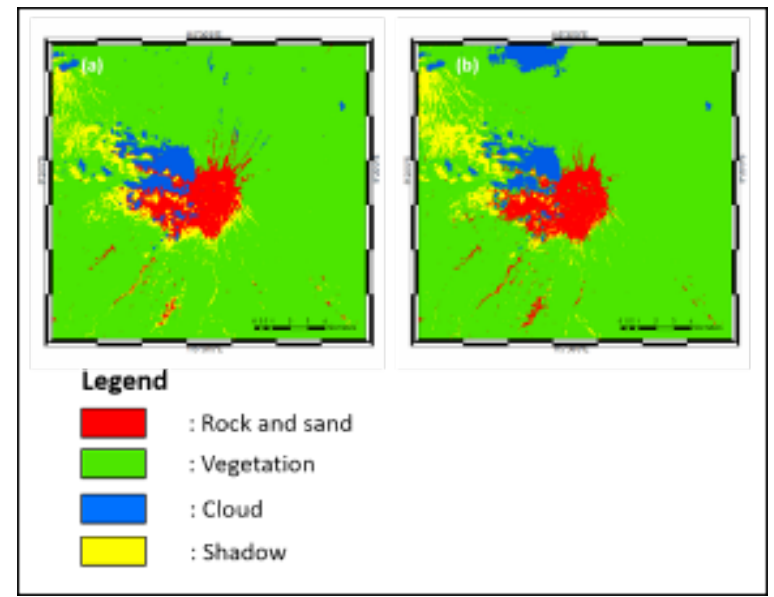

Figure 8. LC maps of Mount Agung after the second eruption created from Landsat-8 images classified with the (a) ANN and (b) SVM methods. LC was classified into four classes: rock and sand (red), vegetation (green), cloud (blue), and shadow (yellow).

\subsubsection{Accuracy Assessment}

Error matrices for LC maps of Mount Agung after the second eruption classified using the ANN and SVM methods are shown in Tables 6 and 7. Accuracy assessment used 551 pixels for the ANN method: 144 pixels for rock and sand, 161 pixels for vegetation, 114 pixels for cloud, and 132 pixels for shadow. The SVM method classified 139 pixels as rock and sand, 178 pixels as vegetation, 112 pixels as cloud, and 122 pixels as shadow. The ANN method had better overall accuracy (97\%) than the SVM method (92\%). User accuracy and producer accuracy were higher for the ANN method (92.81\%) than the SVM method $(86.93 \%)$ in the rock and sand class (i.e., ANN classified pyroclastic materials better than SVM). The kappa coefficients were $87.80 \%$ for ANN and $92.89 \%$ for SVM.

Table 6. Error matrix for LC map of Mount Agung after the second eruption classified using the ANN method.

\begin{tabular}{lllllll}
\hline & $\begin{array}{c}\text { Rock } \\
\text { and } \\
\text { sand }\end{array}$ & $\begin{array}{c}\text { Vege } \\
\text { tatio } \\
\mathbf{n}\end{array}$ & $\begin{array}{c}\text { Clou } \\
\mathbf{d}\end{array}$ & $\begin{array}{c}\text { Shado } \\
\mathbf{w}\end{array}$ & $\begin{array}{c}\text { Class } \\
\text { totals }\end{array}$ & $\begin{array}{c}\text { User } \\
\text { accuracy } \\
(\%)\end{array}$ \\
\hline Rock and sand & 142 & 0 & 1 & 1 & 144 & 98.61 \\
Vegetation & 4 & 157 & 0 & 0 & 161 & 97.52
\end{tabular}




\begin{tabular}{lllllll} 
Cloud & 0 & 0 & 114 & 0 & 114 & 100.00 \\
$\begin{array}{l}\text { Shadow } \\
\begin{array}{l}\text { Reference } \\
\text { totals }\end{array}\end{array}$ & 7 & 5 & 0 & 120 & 132 & 90.91 \\
$\begin{array}{l}\text { Producer } \\
\text { accuracy (\%) }\end{array}$ & 92.81 & 96.91 & 99.13 & 99.17 & & \\
$\begin{array}{l}\text { Overall } \\
\text { accuracy (\%) }\end{array}$ & 97 & 97 & & & & \\
$\begin{array}{l}\text { Kappa } \\
\text { coefficient (\%) }\end{array}$ & 96 & 96 & & & & \\
\hline
\end{tabular}

Table 7. Error matrix for LC map of Mount Agung after the second eruption classified using the SVM method.

\begin{tabular}{llllllc}
\hline & $\begin{array}{c}\text { Rock } \\
\text { and } \\
\text { sand }\end{array}$ & $\begin{array}{c}\text { Vege } \\
\text { tatio } \\
\text { n }\end{array}$ & $\begin{array}{c}\text { Clou } \\
\mathbf{d}\end{array}$ & $\begin{array}{c}\text { Shad } \\
\text { ow }\end{array}$ & $\begin{array}{c}\text { Class } \\
\text { totals }\end{array}$ & $\begin{array}{c}\text { User } \\
\text { accuracy } \\
\text { (\%) }\end{array}$ \\
\hline Rock and sand & 133 & 0 & 1 & 5 & 139 & 95.68 \\
Vegetation & 20 & 152 & 6 & 0 & 178 & 85.39 \\
Cloud & 0 & 4 & 108 & 0 & 112 & 96.43 \\
Shadow & 0 & 6 & 0 & 116 & 122 & 95.08 \\
$\begin{array}{l}\text { Reference } \\
\text { totals }\end{array}$ & 153 & 162 & 115 & 121 & 551 & \\
$\begin{array}{l}\text { Producer } \\
\text { accuracy (\%) }\end{array}$ & 86.93 & 93.83 & 93.91 & 95.87 & & \\
$\begin{array}{l}\text { Overall } \\
\text { accuracy (\%) }\end{array}$ & 92 & 92 & & & & \\
$\begin{array}{l}\text { Kappa } \\
\text { coefficient (\%) }\end{array}$ & 91 & 91 & & & & \\
\hline
\end{tabular}

\section{Conclusions}

The ANN and SVM algorithms both successfully classified LC on Landsat images of Mount Agung. ANN classifications were more accurate than those performed using the SVM method for post-eruption images of Mount Agung. Based on these results, ANN is suitable for LC classification even with a small number of pixels. Overall, both classifiers were able to accurately distinguish pyroclastic material such as lahar, volcanic rock, and sand. Because spatial 
resolution affects LC accuracy, high-resolution images provided better LC accuracy results. Information provided by LC maps can be used in the generation of maps of disaster-prone regions, particularly pyroclastic material debris area. Therefore, the results of the current study may be useful for predicting the susceptibility of volcanic regions to pyroclastic debris damage.

\section{Acknowledgments}

This research was supported by a grant from the National Research Foundation of Korea, provided by the Korea government (No. 2017R1A2B4003258).

\section{References}

Asner, G. P. (2001). Cloud cover in Landsat observation of the Brazilian Amazon. International Journal of Remote Sensing, 22(18), 3855-3862.

Blong, R.J. (1984). Volcanic Hazards: A Sourcebook on the Effects of Eruptions. Academic Press, Orlando, Florida.

Calomarde, R. (1998). An application of remote sensing and geographic information system (GIS): A case study in Sto. Tomas-Marela River, Mt. Pinatubo, Zambales, Philippines. In Asian conference on remote sensing, Manila.

Castro, O. T. \& Carranza, E. J. M. (2004). Remote sensing of temporal variations in spatial distributions of lahar and pyroclastic-flow deposits, West Mount Pinatubo, Philippines. In Erasmi et al. eds., Proceedings of GGRS2004: 1st Göttingen GIS \& Remote Sensing days: Environmental studies, 7-8 October 2004. (Göttinger Geographische Abhandlungen; 113) ISBN 3-88452-113-6. pp. 223-229.

Cohen, J.A. (1960). A coefficient of agreement for nominal scales. Educational and Psychological Measurement, 20, 37-46.

Dilmy, A. (1965). Pioneer plants found one year after the 1963 eruption of Agung in Bali. Pacific Science, 19(4), 498-501.

Dixon, B., \& Candade, N. (2008). Multispectral landuse classification using neural networks and support vector machines: One or the other, or both? International Journal of Remote Sensing, 29(4), 1185-1206.

Foody, G. M. (1996). Relating the land-cover composition of mixed pixels to artificial neural network classification output. Photogrammetric Engineering and Remote Sensing, 62(5), 491-498.

Foody, G. M. (2000). Mapping land cover from remotely sensed data with a softened feedforward neural network classification. Journal of Intelligent and Robotic Systems, 29(4), 433-449. 
Foody, M. G. \& Mathur, A. (2004a). A relative evaluation of multiclass image classification by support vector machines. IEEE Transactions on Geoscience and Remote Sensing, 42, 1335-1343.

Foody, M. G. \& Mathur, A. (2004b). Toward intelligent training of supervised image classifications: Directing training data acquisition for SVM classification. Remote Sensing of Environment, 93, 107-117.

Gertisser, R., Deegan, F. M., Troll, V. R. \& Preece, K. (2018). When the gods are angry: Volcanic crisis and eruption at Bali's great volcano. Geology Today, 34(2), 62-65.

Global Volcanism Program, 2018. Report on Agung (Indonesia). Bulletin of the Global Volcanism Network, 43(1).

Hansen, M., Dubayah, R. \& DeFries, R. (1996). Classification trees: An alternative to traditional land cover classifiers. International Journal of Remote Sensing, 17(5), 1075-1081.

Hepner, G., Logan, T., Ritter, N. \& Bryant, N. (1990). Artificial neural network classification using a minimal training set: Comparison to conventional supervised classification. Photogrammetric Engineering and Remote Sensing, 56(4), 469473.

Joyce, K.E., Samsonov, S., Jongens, R., Lee, J.M. \& Glassey, P.J. (2008). Using remote sensing for mapping the effects of natural hazards in New Zealand. Proceedings of IEEE International Geoscience and Remote Sensing Symposium, Boston, MA, 2, 1251-54.

Joyce, K. E., Belliss, S. E., Samsonov, S. V., McNeill, S. J. \& Glassey, P. J. (2009). A review of the status of satellite remote sensing and image processing techniques for mapping natural hazards and disasters. Progress in Physical Geography, 33(2), 183-207.

Kadavi, P. R., Lee, W. J. \& Lee, C. W. (2017). Analysis of the pyroclastic flow deposits of Mount Sinabung and Merapi using Landsat imagery and the artificial neural networks approach. Applied Sciences, 7(9), 935.

Kavzoglu, T. (2009). Increasing the accuracy of neural network classification using refined training data. Environmental Modelling \& Software, 24(7), 850-858.

Kerle, N., Froger, J.L., Oppenheimer, C. \& de Vries, B.V. (2003). Remote sensing of the 1998 mudflow at the Casita volcano, Nicaragua. International Journal of Remote Sensing, 24, 4791-816.

Khorram, S. ed. (1999). Accuracy Assessment of Remote Sensing-derived Change Detection. ASPRS Publications.

Kusumadinata, K. (1979). Dasar Gunungapi Indonesia, Direktorat Vulkanolog. Available at: http://www.vsi.esdm.go.id/index.php/gunungapi/data-dasargunungapi/468-g-agung.

Liu, Q., Guo, Y., Liu, G. \& Zhao, J. (2014). Classification of Landsat 8 OLI image using support vector machine with tasseled cap transformation. In Natural Computation (ICNC), 2014 10th International Conference on IEEE. pp. 665-669.

Liu, M., Wang, M., Wang, J. \& Li, D. (2013). Comparison of random forest, support vector machine and back propagation neural network for electronic tongue data classification: Application to the recognition of orange beverage and Chinese vinegar. Sensors and Actuators B: Chemical, 177, 970-980. 
Lu, D., Batistella, M., Li, G., Moran, E., Dutra, L.V., Freitas, C.C. \& Sant'Anna, S.J. (2012). Land use/cover classification in the Brazilian Amazon using satellite images. Pesquisa Agropecuaria Brasileira, 47(9).

Mazher, A., Li, P. \& Zhang, J. (2012). Mapping burned areas from Landsat TM images: a comparative study. In Computer Vision in Remote Sensing (CVRS), 2012 International Conference on IEEE. pp. 285-290.

Mountrakis, G., Im, J. \& Ogole, C. (2011). Support vector machines in remote sensing: A review. ISPRS Journal of Photogrammetry and Remote Sensing, 66(3), 247259.

Pal, M. \& Mather, P. M. (2003). An assessment of the effectiveness of decision tree methods for land cover classification. Remote Sensing of Environment, 86(4), 554565.

Parvathy, S. (2014). Change Detection In Land Use/Land Cover Using Remote Sensing in Palakkad district: A Case Study. 15th ESRI India User Conference 2014. Available at: http://www.esriindia.com/ /media/esriindia/files/pdfs/events/uc2014/proceedings.

Pieri, D. \& Abrams, M. (2004). ASTER watches the world's volcanoes: A new paradigm for volcanological observations from orbit. Journal of Volcanology and Geothermal Research, 135(1-2), 13-28.

Pugnaghi, S., Gangale, G., Corradini, S. \& Buongiorno, M. F. (2006). Mt. Etna sulfur dioxide flux monitoring using ASTER-TIR data and atmospheric observations. Journal of Volcanology and Geothermal Research, 152(1-2), 74-90.

Realmuto, V. J., Sutton, A. J. \& Elias, T. (1997). Multispectral thermal infrared mapping of sulfur dioxide plumes: A case study from the East Rift Zone of Kilauea Volcano, Hawaii. Journal of Geophysical Research: Solid Earth, 102(B7), 1505715072.

Sanyal, J. \& Lu, X. X. (2004). Application of remote sensing in flood management with special reference to monsoon Asia: A review. Natural Hazards, 33(2), 283-301.

Smith, A. M. S., Wooster, M. J., Powell, A. K. \& Usher, D. (2002). Texture based feature extraction: Application to burn scar detection in Earth observation satellite sensor imagery. International Journal of Remote Sensing, 23(8), 1733-1739.

Torres, R., Mouginis-Mark, P., Self, S., Garbeil, H., Kallianpur, K. \& Quiambao, R. (2004). Monitoring the evolution of the Pasig-Potrero alluvial fan, Pinatubo Volcano, using a decade of remote sensing data. Journal of Volcanology and Geothermal Research, 138(3-4), 371-392.

Townshend, J. R., Masek, J. G., Huang, C., Vermote, E. F., Gao, F., Channan, S. \& Song, K. (2012). Global characterization and monitoring of forest cover using Landsat data: opportunities and challenges. International Journal of Digital Earth, 5(5), 373-397.

Tralli, D. M., Blom, R. G., Zlotnicki, V., Donnellan, A. \& Evans, D. L. (2005). Satellite remote sensing of earthquake, volcano, flood, landslide and coastal inundation hazards. ISPRS Journal of Photogrammetry and Remote Sensing, 59(4), 185-198.

Tseng, M. H., Chen, S. J., Hwang, G. H. \& Shen, M. Y. (2008). A genetic algorithm rule-based approach for land-cover classification. ISPRS Journal of Photogrammetry and Remote Sensing, 63(2), 202-212. 
Turner, W., Rondinini, C., Pettorelli, N., Mora, B., Leidner, A. K., Szantoi, Z. \& Koh, L. P. (2015). Free and open-access satellite data are key to biodiversity conservation. Biological Conservation, 182, 173-176.

Wang, Q., Wu, C., Li, Q. \& Li, J. (2010). Chinese HJ-1A/B satellites and data characteristics. Science China Earth Sciences, 53(1), 51-57.

Van Westen, C. J. (2000). Remote sensing for natural disaster management. International Archives of Photogrammetry and Remote Sensing, 33(B7/4, Part 7), 1609-1617.

Watanachaturaporn, P., Varshney, P. K. \& Arora, M. K. (2004). Evaluation of factors affecting support vector machines for hyperspectral classification. In American Society for Photogrammetry \& Remote Sensing (ASPRS) 2004 Annual Conference, Denver, $C O$.

Wheller, G. E. \& Varne, R. (1986). Genesis of dacitic magmatism at Batur volcano, Bali, Indonesia: implications for the origins of stratovolcano calderas. Journal of Volcanology and Geothermal Research, 28(3-4), 363-378.

Whitford, DJ (1975) Strontium isotopic studies of the volcanic rocks of the Sunda arc, Indonesia, and their petrogenetic implications. Geochim Cosmochim Acta, 39:1287-1302.

Xiu, L. N. \& Liu, X. G. (2003). Current status and future direction of the study on artificial neural network classification processing in remote sensing. Remote Sensing Technology and Application, 18, 339-345.

Yao, X., Tham, L. G. \& Dai, F. C. (2008). Landslide susceptibility mapping based on support vector machine: a case study on natural slopes of Hong Kong, China. Geomorphology, 101(4), 572-582.

Zen, M. T. \& Hadikusumo, D. (1964). Preliminary report on the 1963 eruption of Mt. Agung in Bali (Indonesia). Bulletin of Volcanology, 27, 269-299. 10.1007/BF02597526.

Zhai, S. \& Jiang, T. (2014). A novel particle swarm optimization trained support vector machine for automatic sense-through-foliage target recognition system. Knowledge-Based Systems, 65, 50-59.

Zhan, X., Sohlberg, R. A., Townshend, J. R. G., DiMiceli, C., Carroll, M. L., Eastman, J. C. \& DeFries, R. S. (2002). Detection of land cover changes using MODIS 250 $\mathrm{m}$ data. Remote Sensing of Environment, 83(1-2), 336-350.

The English in this document has been checked by at least two professional editors, both native speakers of English. For a certificate, please see:

http://www.textcheck.com/certificate/tMPfuX 